\title{
Technology Readiness on Information Technology Performance at Contractors Company
}

\author{
R. Panday ${ }^{1}$ \\ \{Indripan @ gmail.com ${ }^{1}$ \} \\ ${ }^{1}$ Faculty of Economics, Bhayangkara Jakarta Raya University, Jl. Raya Perjuangan, \\ Margamulya, Bekasi Utara, Indonesia
}

\begin{abstract}
Nowadays the execution of a project, which related to project data, cash flow, use of project material, workers data, project schedules, and drawings, are mostly carried out using computer technology, better known as Information Technology (IT). For that, requires prime of IT performance that consists of hardware, software, and operators. The execution IT, a skilled and skillful workforce is needed in using the technology, thus supporting the smooth running of the project, which is called the level of technology readiness of the operators. This study examines how much influence the level of technology readiness has on the performance of the IT system used.The research data was taken using questionnaires, with workers respondents using IT at PT. DENKI contractor company, as many as 30 respondents which done in October 2018. Data were processed using the regression analysis in SPSS, 24 version. The results of this study indicated that three of the four technology readiness variables have a positive and significant effect on the performance of the IT system performance, namely Optimism, Discomfort, and Insecurity, while the Innovativeness variable does not affect on IT system performance. Based on the result, the managerial action arranged to increase the IT system performance.
\end{abstract}

Keywords: Technology Readiness, Optimism, Innovativeness, Discomfort, Insecurity, IT system performance

\section{Introduction}

Technology has developed very quickly, so that with this development may affect human activities, moreover with the development of computer technology and software and information systems known as information technology (IT). IT has been widely used in various organizations [1]. With IT it has been able to increase efficiency and effectiveness, and ultimately improve productivity and quality [2]. IT is also widely used in building, electrical and mechanical contractors on their projects. The use of IT in projects includes drawing, financial management, human resource management, operational management, raw material management, and supply chain, project administration. The use of such a large number of IT, of course, requires excellent IT equipment, capable IT personnel so that it will show the IT system performance excellence. Capable IT personnel, of course, experts who have high technology readiness, as has been suggested by many researchers.

PT.DENKI is a contracting company in the electrical and mechanical fields, located in Bekasi City. In carrying out its work, this company has used information technology (IT) system, for the purposes of drawing, making project schedules, financial management, using raw materials, managing human resources and business communication electronically using email. The company uses selected IT experts at the time of employee recruitment according 
to applicable procedures. It is expected that using IT and selected IT personnel can increase efficiency and effectiveness so that it will increase productivity.

However, in the implementation of the project, there were many problems related to IT, such as the existence of several activities using IT, slow of progress, which could be because the IT personnel are not ready to accept the technology used. There are still sections of the work done manually. There are some IT personnel who have not been able to transform their working habits from working manually switching using IT. Another thing, some experts assess the state of hardware and software is not the latest technology. Some even have not really understood how to use available hardware and software. With this, it will have an impact on the performance of the IT system. Interestingly in this incident, there are two things, namely IT personnel and IT system performance. The thing that is related to IT personnel is technology readiness, have been discussed by Parasuraman in their theory of technology readiness.

The purpose of this study to analyze the technology readiness to the performance implementation of IT technology at PT.DENKI. How is the level of technology readiness at PT. DENKI? This research may give benefit to the company to improve the IT performance at PT. DENKI, and finally to improve the quality of project activities.

\section{Literature Review}

Research on technology readiness has been carried out by researchers from various countries and various types of technology used. Everything starts with the theory of technology readiness which was first developed by Parasuraman. Technology readiness has 4 dimensions namely Optimism, Innovativeness, Discomfort and Insecurity.

$>$ Optimism is a positive view of technology and the belief that technology can improve control, be more flexible and efficient in their lives. [3]. It generally captures positive feelings about technology.

$>$ Innovativeness is a tendency become technology pioneer and thought leader[3]. This dimension generally measures to what degree individuals perceive themselves as forefront.

$>$ Discomfort is a perceived lack of control over technology and a feeling of being overwhelmed by it [3]. This dimension generally measures the fear and concerns people experience when confronted with technology.

$>$ Insecurity is distrust of technology and skepticism about its ability to work properly [3]. This dimension focuses on concerns people may have in face of technologybased transactions.

Optimism and Innovativeness are drivers of technology readiness (TR). A high score on these dimensions will increase overall technology readiness. Discomfort and Insecurity, on the other hand, are inhibitors of technology readiness. The high score on these dimensions will reduce overall technology readiness [4]. Results show that the four dimensions are fairly independent, each of them making a unique contribution to an individual's technology readiness [3]. In this study used TRI, which "people's propensity to embrace and use new technologies to accomplish goals in home life and at work" will predict to IT system performance.

In describing of TR, Parasuraman and Colby (2001) identify five distinct groups: Explorers, Pioneers, Skeptics, Paranoids, and Laggards. Explorers score higher on the contributors (optimism, innovativeness) and lower on inhibitors (discomfort, insecurity) than the other segments. Explorers are a relatively easy group to attract when a new technology- 
based product or service is introduced and represent the first wave of customers. Laggards are the opposite of Explorers, ranking lower on the contributory factors and higher on the inhibitor factors than all the groups as a whole. Laggards are also typically the last group to adopt a new technology-based product or service. The middle three segments (Pioneers, Skeptics, and Paranoids) have more complicated beliefs about technology. Pioneers share the optimism and innovative beliefs of Explorers, but they simultaneously feel some discomfort and insecurity. They desire the benefits of technology but are more practical about the difficulties and challenges. Skeptics tend to be dispassionate about technology, but also have few inhibitions; thus, they need to be convinced of the benefits. Paranoids may find technology interesting, but they are also concerned about risks and exhibit high degrees of discomfort and insecurity [5]. According to Parasuman's results, Table 1 shows the characteristics of technology segments (Jaafar, Mastura, Abdul Aziz, Abdul Rashid, Ramayah, T., and Saad, 2007) [7].

Table 1. The characteristics of technology segments

\begin{tabular}{ccccc}
\hline & Optimism & Innovativeness & Discomfort & Insecurity \\
\hline Explorers & High & High & Low & Low \\
Pioneers & High & High & High & High \\
Skeptics & Low & Low & Low & Low \\
Paranoids & High & Low & High & High \\
Laggards & Low & Low & High & High \\
\hline
\end{tabular}

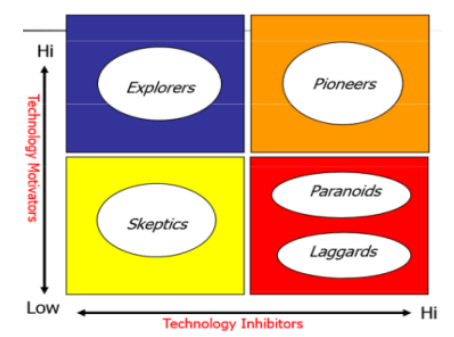

Fig 1. Five TR Segments

The TRI model has been used by several researchers such as [8], and, [9] and ;[10]. TRI has been used by many researchers such as :[11], with their research on mobile electronic medical record systems operated by nurses;[12], their research on E-HRM; [13], their research on Social Media Context;[14], their research on application computer at UMKM;[15], [16], their research on $\mathrm{M}$ (mobile)-Payment; [2] have used technology readiness in using Academic Information System by student and lecturer at X University. (Panday, 2015) also used TRI integrated with TAM model to test the model on Academic Information System. [18] also used TRI in TRAM to test the model on Geodesy student in data processing of Geographic Information system data, and last, [1] has used TRI integrated into TRAM on project management data processing at PT. Pembangunan Perumahan. All research by R.Panday, showed different result each other and in different condition and different subject. 
To see the related research, the reported study in this paper is the implementation of TRI to the electrical and mechanical project at Contractor company, to see the level of technology readiness influence to IT system performance.

\section{Method}

The method used in this study is the quantitative method. Data were taken by questionnaires, which is a modification of the questionnaires made by Parasuraman. The technology readiness variables as independent variables, and the IT system performance as the dependent variable. After data collected, computation use SPSS 24 version. The nalysis in this research used multiple regression.

\section{Result and Discussion}

Before the analysis is carried out, the validity and reliability of the questionnaire is first tested. The results of the validity in table- 2 and table- 3 .

Table2. Results of the Technology Readiness Validity

\begin{tabular}{llllllllll}
\hline O1 & O2 & O3 & O4 & O5 & O6 & O7 & O8 & O9 & O10 \\
$.825^{* *}$ & $.805^{* *}$ & $.842^{* *}$ & $.738^{* *}$ & $.844^{* *}$ & $.718^{* *}$ & $.758^{* *}$ & $.881^{* *}$ & $.864^{* *}$ & $.738^{* *}$ \\
IN1 & IN2 & IN3 & IN4 & IN5 & IN6 & IN7 & & & \\
$.778^{* *}$ & $.842^{* *}$ & $.736^{* *}$ & $.779^{* *}$ & $.803^{* *}$ & $.800^{* *}$ & $.677^{* *}$ & & & \\
D1 & D2 & D3 & D4 & D5 & D6 & D7 & D8 & D9 & D10 \\
$.794^{* *}$ & $.785^{* *}$ & $.786^{* *}$ & $.748^{* *}$ & $.855^{* *}$ & $.878^{* *}$ & $.361^{*}$ & $.397^{*}$ & $.559^{* *}$ & $.822^{* * *}$ \\
INS1 & INS2 & INS3 & INS4 & INS5 & INS6 & INS7 & INS8 & INS9 & \\
$.774^{* * *}$ & $.719^{* *}$ & $.743^{* *}$ & $.818^{* *}$ & $.696^{* *}$ & $.788^{* *}$ & $.633^{* *}$ & $.699^{* *}$ & $.564^{* *}$ & \\
\hline
\end{tabular}

From the results of the validity computation, all indicators of the variables show significant values, so that the results of the questionnaire are valid. The results of the reliability computation showed in table 3, that the Cronbach alpha value is greater than 0.6 so that it can be said that the questionnaire used is reliable.

Table 3. Reliability result calculation

\begin{tabular}{cccc}
\hline \multicolumn{4}{c}{ Alpha Cronbach } \\
Optimism & Innovativeness & Discomfort & Insecurity \\
\hline 0.937 & 0.887 & 0.895 & 0.880 \\
\hline
\end{tabular}

The average value of each Technology readiness variable is shown in table- 4 . The average value of Optimism variable is 3.70 , it is meant to be high, meaning that the respondent's view on the technology used is positive and they believe it will improve control, flexibility, and efficiency in their lives. The average value of the Innovativeness variable is 3.49 , it said to be high, meaning that the respondents have a tendency as technology pioneers and think forward. Because these two variables can be said to be high, the two variables are a powerful driver of technology readiness of each respondent. The average value of the 
discomfort variable is 3.48 and the average insecurity value is 3.70 , each can be said to be high; this is meaningful, the inhibitor variable from technology readiness is still high, thus will reducing the value of overall technology readiness. These two values should have a low or very low average value if want to high technology readiness. Because of all value of TRI variables are high, so the respondent in this research as the segment of the pioneer on technology readiness. Average value of IT system performance is 4.10 , indicate high performance.

Table 4. Average value of technology readiness variables

\begin{tabular}{ccccc}
\hline Optimism & $\begin{array}{c}\text { Innovative- } \\
\text { ness }\end{array}$ & $\begin{array}{c}\text { Average value } \\
\text { Discomfort }\end{array}$ & Insecurity & $\begin{array}{c}\text { IT System } \\
\text { Performance }\end{array}$ \\
\hline 3.70 & 3.49 & 3.48 & 3.70 & 4.10 \\
High & High & High & High & High \\
\hline
\end{tabular}

The following is a regression model which can be seen in Table 5 and Table 6 . This regression model shows a strong model, because the Test value $f=21,845$ on sig 0,000 , means that all variable technology readiness significantly affects the performance of the IT system and contributes to the performance of the IT system by $77.8 \%$. This model is also supported by data that has no autocorrelation indicated by the value of Durbin Watson 2,358.

Table 5. Model Summary

\begin{tabular}{|c|c|c|c|c|c|c|c|c|c|c|}
\hline \multirow[b]{2}{*}{ Model } & \multirow[b]{2}{*}{$\mathrm{R}$} & \multirow[b]{2}{*}{$\begin{array}{c}\mathrm{R} \\
\text { Square }\end{array}$} & \multirow{2}{*}{$\begin{array}{c}\text { Adjusted } \\
\text { R } \\
\text { Square }\end{array}$} & \multirow{2}{*}{$\begin{array}{c}\text { Std. } \\
\text { Error of } \\
\text { the } \\
\text { Estimate }\end{array}$} & \multicolumn{5}{|c|}{ Change Statistics } & \multirow[b]{2}{*}{$\begin{array}{l}\text { Durbin- } \\
\text { Watson }\end{array}$} \\
\hline & & & & & $\begin{array}{l}\text { Square } \\
\text { Change }\end{array}$ & $\begin{array}{c}\mathrm{F} \\
\text { Change }\end{array}$ & df1 & df2 & $\begin{array}{c}\text { Sig. F } \\
\text { Change }\end{array}$ & \\
\hline 1 & $.882^{\mathrm{a}}$ & .778 & .742 & .385 & .778 & 21.845 & 4 & 25 & .000 & 2.358 \\
\hline
\end{tabular}

a. Predictors: (Constant), Optimism, Innovativeness, Discomfort, Insecurity

b. Dependent Variable: IT System Performance

Table 6. ANOVA

\begin{tabular}{ll|r|r|r|r|r}
\hline Model & & Sum of Squares & df & Mean Square & \multicolumn{1}{c}{ F } & Sig. \\
\hline \multirow{2}{*}{1} & Regression & 12.985 & 4 & 3.246 & 21.845 & $.000^{\mathrm{b}}$ \\
\cline { 2 - 7 } & Residual & 3.715 & 25 & .149 & & \\
\cline { 2 - 7 } & Total & 16.700 & 29 & & & \\
\hline
\end{tabular}

a. Dependent Variable: IT System Performance

b. Predictors: (Constant), Optimism, Innovativeness, Discomfort, Insecurity

How is the influence of each variable technology readiness seen in Table 7, where the significant variable influencing the performance of the IT system is the Optimism variable 
with the value of t-count $=8,072$ on the sig level 0,000 , giving a positive influence, Discomfort variable with $\mathrm{t}$ count $=2.863$ on sig 0.008 level gives a positive influence and Insecurity variable with $\mathrm{t}$ count $=2.190$ on sig Level 0.038 gives a negative influence. In this case, the sig.level value is smaller than 0.05. While the Innovativeness variable is not significant, because the t-count value is smaller than 2 and sig. The level is greater than 0.05 .

Table 7. Coefficients

\begin{tabular}{|c|c|c|c|c|c|c|}
\hline \multirow{2}{*}{\multicolumn{2}{|c|}{ Model }} & \multicolumn{2}{|c|}{$\begin{array}{c}\text { Unstandardized } \\
\text { Coefficients }\end{array}$} & \multirow{2}{*}{$\begin{array}{c}\text { Standardized } \\
\text { Coefficients } \\
\text { Beta } \\
\end{array}$} & \multirow[b]{2}{*}{$\mathrm{t}$} & \multirow[b]{2}{*}{ Sig. } \\
\hline & & B & Std. Error & & & \\
\hline \multirow[t]{5}{*}{1} & (Constant) & -1.035 & .842 & & -1.230 & .230 \\
\hline & Optimism & .093 & .012 & .791 & 8.072 & .000 \\
\hline & Innovativeness & .007 & .025 & .030 & .279 & .782 \\
\hline & Discomfort & .092 & .032 & .450 & 2.863 & .008 \\
\hline & Insecurity & -.062 & .028 & -.344 & -2.190 & .038 \\
\hline
\end{tabular}

a. Dependent Variable: IT System Performance

Based on the Standardized value, the variable Optimism shows the greatest influence on IT system performance, followed by variable Discomfort and Insecurity variables. However, the positive influence of variable discomfort is contrary to the characteristics of the variable, which should have a negative effect, because the variable discomfort is the variable that is an inhibitor, which is a negative impact.

\subsection{Managerial Implication}

The existence of three variable technology readiness that significantly affects the performance of IT systems, one variable technology readiness that is not significant, has implications for improving or maintaining the performance of the IT system. In this case the IT system performance has shown very good performance. The optimism of the highperforming personnel shows that the respondent's view on the technology used is positive and they believe it will improve control, flexibility, and efficiency in their lives. The behavior of this optimism must be maintained by continuing to ensure that IT technolog,y does improve control, flexibility, efficiency in their work. High Discomfort properties and a positive effect on IT system performance, shows a contrary to theory. The company should be given training and the supervision of IT personnel so that in the end they feel comfortable using IT. The behavior of Insecurity is also still high, but it is in accordance with the TRI theory, giving a negative influence. To reduce high insecurity, the company continues to conduct training and supervision of IT personnel when using the IT system, until their insecurity shrinks. For the innovative behavior of Innovativeness, but it does not have a significant effect on the performance of IT systems, companies must check the innovations made by personal IT, whether they can support the performance of IT systems. If it has not been supported, the company must direct IT personnel so that innovations made really support the performance of the IT system. 


\section{Conclusion}

The conclusions of this study are:

1. Overall the technology readiness that occurs is high and has a significant effect on the performance of the IT system

2. Three variable technology readiness significantly influence the performance of the IT system, but one variable contrary to the TRI theory

3. Innovativeness variables have no significant effect on IT system performance

\section{References}

[1] R. Panday, "Evaluation of Technology Readiness-Acceptance in Operation of Project Management Services," 2015.

[2] R. Panday and J. T. Purba, "Lecturers and students technology readiness in implementing services delivery of academic information system in higher education institution: A case study," in Communications in Computer and Information Science, 2015, vol. 516, pp. 539-550.

[3] C. L. Parasuraman, A., \& Colby, Techno-ready marketing: How and why your customers adopt technology. New York: Free Press., 2001.

[4] A. Parasuraman, "Technology readiness index (TRI): A multiple-item scale to measure readiness to embrace new technologies," J. Serv. Res., vol. 2, 2000.

[5] M. M. Massey, Anne P., Khatri, Vijay, and Montoya-Weiss, "Usability of Online Services: The Role of Technology Readiness and Context," Decis. Sci., vol. Vol.38(2), p. $277,2007$.

[6] B. Jaafar, Mastura, Abdul Aziz, Abdul Rashid, Ramayah, T., and Saad, "Integrating Information Technology in the Construction Industry: Technology Readiness Assessment of Malaysian Contractors," Int. J. Proj. Manag., vol. Vol. 25(2), pp. 115120, 2007.

[7] N. Tsikriktsis, "A technology readiness-based taxonomy of costumers: A replication and extension," J. Serv. Res., vol. 4, p. 42=45, 2004.

[8] \& W. Y.-L. Lin, C.-H., Shih, H.-Y., Sher, P. J., "Consumer adoption of e-service: Integrating technology readiness with the technology acceptance model.," in Proceedings of PICMET '05: Technology Management: A Unifying Discipline for Melting the Boundaries, 2005, pp. 483-488.

[9] V. Venkatesh, "Determinants of perceived ease of use: Integrating control, intrinsic motivation, and emotion into the technology acceptance model.," Inf. Syst. Res., pp. 342-365, 2000.

[10] M. Schepers, J., \& Wetzels, "A meta-analysis of the technology acceptance model: Investigating subjective norm and moderation effects," Inf. Manag., pp. 90-103, 2007.

[11] C.-F. L. and C.-C. M. Kuang-Ming Kuo, "An investigation of the effect of nurses'technology readiness on the acceptance of mobile electronic medical record systems," BMC Med. Inform. Decis. Mak., 2013.

[12] N. E. Murat Esen, "Effects of Technology Readiness On Technology Acceptance In E-HRM: Mediating Role of Perceived Usefulness," 2014.

[13] M. K. Anders Husa, "The TRAM Framework in a Social Media Context - Measuring Attitudes Towards Consumer-Company Interaction” A Study of Norwegian Social Media Users.," 2009.

[14] E. M. S. Mimin Nur Aisyah, Mahendra Adhi Nugroho, "Pengaruh Technology Readiness Terhadap Penerimaan Teknologi komputer Pada UMKM di Yogyakarta," 
2013.

[15] J. Yen, "Perspectives from the TRAM Model on Adopting e-Learning: An Analysis of the Chain and Franchise Industry in Taiwa," no. 25januari 2015, 2014.

[16] and M. H. B. Nadine Guhr, Tai Loi, Rouven Wiegard, "Technology Readiness in Customers' Perception and Acceptance of M(obile)-Payment: An Empirical Study in Finland, Germany, the USA and Japan.," in Germany 11 th International Conference on Wirtschafts informatic, 27thFebruary - 01st March 2013, 2013.

[17] R. Panday, "The Effect of Technology Readiness on Technology Acceptance in Using Services Delivery of Academic Information System,” 2015, pp. 978-979.

[18] R. Panday, "Analysis of technology readiness and technology acceptance of geodesy student in using ina geoportal," no. November, pp. 10-12, 2015. 